\title{
Regional impacts of ultrafine particle emissions from the surface of the Great Lakes
}

\author{
S. H. Chung ${ }^{1}$, B. M. Basarab ${ }^{2}$, and T. M. VanReken ${ }^{1}$ \\ ${ }^{1}$ Laboratory for Atmospheric Research, Department of Civil \& Environmental Engineering, Washington State University, \\ Pullman, Washington, USA \\ ${ }^{2}$ Department of Physics, Middlebury College, Middlebury, Vermont, USA
}

Received: 25 April 2011 - Published in Atmos. Chem. Phys. Discuss.: 31 May 2011

Revised: 15 November 2011 - Accepted: 29 November 2011 - Published: 15 December 2011

\begin{abstract}
Quantifying the impacts of aerosols on climate requires a detailed knowledge of both the anthropogenic and the natural contributions to the aerosol population. Recent work has suggested a previously unrecognized natural source of ultrafine particles resulting from breaking waves at the surface of large freshwater lakes. This work is the first modeling study to investigate the potential for this newly discovered source to affect the aerosol number concentrations on regional scales. Using the WRF-Chem modeling framework, the impacts of wind-driven aerosol production from the surface of the Great Lakes were studied for a July 2004 test case. Simulations were performed for a base case with no lake surface emissions, a case with lake surface emissions included, and a default case wherein large freshwater lakes emit marine particles as if they were oceans. Results indicate that the lake surface emissions can enhance the surfacelevel aerosol number concentration by $\sim 20 \%$ over the remote northern Great Lakes and by $\sim 5 \%$ over other parts of the Great Lakes. These results were highly sensitive to the new particle formation (i.e., nucleation) parameterization within WRF-Chem; when the new particle formation process was deactivated, surface-layer enhancements from the lake emissions increased to as much as $200 \%$. The results reported here have significant uncertainties associated with the lake emission parameterization and the way ultrafine particles are modeled within WRF-Chem. Nevertheless, the magnitudes of the impacts found in this study suggest that further study to quantify the emissions of ultrafine particles from the surface of the Great Lakes is merited.
\end{abstract}

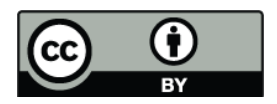

Correspondence to: T. M. VanReken (vanreken@wsu.edu)

\section{Introduction}

Understanding and quantifying the impacts of aerosols on the atmospheric radiative balance is one of the most significant outstanding problems in climate change science (IPCC, 2007). Aerosols can impact the radiative balance directly through their scattering and absorbing properties, and indirectly by influencing the formation and properties of clouds. Much of the uncertainty associated with these so-called direct and indirect aerosol effects results from an insufficient knowledge of the aerosol population itself. A particle's optical properties and ability to form a cloud droplet are each strongly dependent on its physical and chemical properties. Scaling these dependencies up to the aerosol population, i.e., estimating the overall radiative forcing due to the total aerosol present, requires a detailed knowledge of the aerosol size distribution, size-resolved composition, mixing state, and hygroscopic properties. Directly acquiring such detailed knowledge is challenging even during intensive measurement campaigns; amassing a sufficiently complete data set on regional scales or beyond will not be achievable for the foreseeable future. The best available alternative at present is to rely on large-scale models to assimilate the available information of aerosol sources, sinks, and atmospheric transformations and then verify these models with atmospheric observations.

To be successful in building a reliable large-scale atmospheric aerosol model, the natural sources of particulate material must be included as well as the anthropogenic ones. In part this is because after atmospheric aging it is difficult to distinguish anthropogenic and natural aerosol material- validation is most easily approached by considering the sum of all sources. Understanding both the natural and anthropogenic contributions to the aerosol population is especially important when considering aerosol climate impacts, because the most relevant parameters for climate studies are the changes to radiative forcing and the subsequent feedbacks.

Published by Copernicus Publications on behalf of the European Geosciences Union. 
The relationship between an increase in aerosol loading and the resultant radiative forcing is complex and non-linear; understanding the pre-existing natural state of the atmosphere is critical to determining how anthropogenic pollution perturbs the system.

While the sum of natural particle sources far exceeds the total anthropogenic contribution, with some notable exceptions (e.g., volcanoes and forest fires) natural sources tend to be spatially and temporally distributed rather than locally intense. Natural emissions fluxes are characteristically smaller than anthropogenic ones, but are spread over large areas and can persist for long periods of time. Examples of these 'gentle' natural particle sources include marine emissions of sea salt, windblown dust, and pollen releases from forests and grasslands. Despite their low intensity, it is highly likely that all of the major sources of natural aerosols- those that have impacts on global scales- have already been identified if not fully quantified.

Because the emissions intensity of natural sources can be so small locally, they can be easy for researchers to overlook and thus it does still happen that natural particle sources of potential regional importance are discovered from time to time. For example, O'Dowd et al. (1998) observed strong new particle formation events along the Ireland coast under low tide conditions; later work showed conclusively that these particles were the result of the photolysis of iodine-containing compounds emitted from macroalgae exposed during low-tide (O'Dowd et al., 2002). The relatively recent discovery that isoprene can form secondary organic aerosol in the atmosphere is another example. Isoprene is the most abundant volatile organic compound emitted from the biosphere, but for many years the scientific consensus was that its aerosol-forming potential was negligible (Pandis et al., 1991). This consensus was challenged when Claeys et al. (2004) found unexpected evidence of 2-methyltetrols in aerosol samples collected in the Amazon; the most likely mechanism for producing the compounds in the atmosphere is via the photooxidation of isoprene. Focused studies have since shown that isoprene oxidation can yield SOA via both gas-phase and aqueous mechanisms, and it is now believed that isoprene is a significant source of organic aerosol material in many areas of the globe (Henze and Seinfeld, 2006; Kroll et al., 2006). A thorough discussion of these and many other natural sources of particulate material in the atmosphere can be found in the review by Carslaw et al. (2010).

Slade et al. (2010) recently described another new source of natural particles that is potentially significant on regional scales- the production of nanoparticles from breaking waves at the surface of freshwater lakes. In Summer 2009, the Purdue University Airborne Laboratory for Atmospheric Research (ALAR) research aircraft conducted several research flights over the northern parts of Lakes Michigan and Huron in support of the Community Atmosphere-Biosphere Interactions Experiment (CABINEX). The intended purpose of the flights was to determine the "background" condition of the regional aerosol prior to air mass advection over the main CABINEX ground site at the Program for Research on Oxidants: Photochemistry, Emissions, and Transport (PROPHET) facility at the University of Michigan Biological Station (Carroll et al., 2001). Surprisingly, more than just a regional background aerosol was observed during these flights. On several occasions elevated concentrations of nanoparticles were found over the lakes in a distinct $\sim 15-40 \mathrm{~nm}$ mode that was usually not present at the PROPHET site. The available evidence strongly suggests that these particles were the result of natural, wave breaking processes at the lake surface. As described by Slade et al. (2010), the particles were only observed when whitecap waves were present, the concentration of the $15-40 \mathrm{~nm}$ mode was in most cases largest just above the surface, and the concentration of that mode increased exponentially with surface wind speed. Furthermore, a chemical analysis of the lake water indicated that the concentrations of trace constituents (Table S1 of Slade et al., 2010) were cumulatively sufficient to produce a dry particle mode in the $15-40 \mathrm{~nm}$ size range if the size distribution of water-containing droplets emitted from the lake surface were similar to that observed in marine environments.

While the particle production mechanism proposed by Slade et al. (2010) is interesting, it has not yet been definitively established- that would require a more targeted experiment with a more robust set of observations. Moreover, it is not yet clear that the proposed lake surface aerosol source is large enough to be atmospherically relevant on a regional scale. As noted in that initial study, a reasonable estimate of the particulate mass expected from a lake surface source would only be a tiny fraction of the primary emissions from the upwind region; there would be a similarly small relative contribution to specific hazardous pollutants to the atmosphere. These are intuitive results- the particles resulting from the proposed lake surface source have very small diameters and thus have very little mass.

On the other hand, Slade et al. (2010) did indicate that the lake surface source was potentially significant in terms of particle number, comparable to the low end of the range of atmospheric new particle formation rates. Nilsson et al. (2001) measured marine particle fluxes on the order of $10^{6} \mathrm{~m}^{-2} \mathrm{~s}^{-1}$ at atmospherically relevant conditions (wind speed $=10 \mathrm{~m} \mathrm{~s}^{-1}$, height $=10 \mathrm{~m}$ ); averaged through the lowest $100 \mathrm{~m}$ of the atmosphere, this would correspond to a new particle source rate of $\sim 0.01 \mathrm{~cm}^{-3} \mathrm{~s}^{-1}$. This "equivalent" source rate is only a rough estimate, but it is consistent with the low end of range of atmospheric new particle formation rates reported by Kulmala et al. (2004) and it is reasonable to speculate that wind-driven surface emission events could last longer and thus have similar overall impact than chemically-driven new particle formation events. This is key, because several studies have demonstrated that atmospheric new particle formation can influence the aerosol indirect climate effect by increasing cloud condensation nuclei $(\mathrm{CCN})$ 
concentrations (e.g., Kuang et al., 2009; Merikanto et al., 2009; Pierce and Adams, 2009; Yu and Luo, 2009). The mechanism for the nanoparticles derived from lake surfaces to impact climate would be similar- they would potentially impact how the aerosol population evolves due to condensational growth and its cloud forming potential. If the lake surface emissions mechanism is valid, these impacts would exist, but it is not clear whether they would be important on the temporal and spatial scales relevant to regional climate.

This study examines the potential for a lake-surface nanoparticle source to affect the aerosol population on regional scales. With finer spatial and temporal scales than those of global climate models, mesoscale models are better suited for a detailed analysis of regional aerosol emissions and processing. Using the WRF-Chem mesoscale model, we will look at the impacts of wind-driven lake surface nanoparticle emissions on total aerosol number concentrations for an exemplary case in the Great Lakes region. First, for a detailed analysis, a period has been selected that is characterized by high surface winds over an extended $(\sim$ several hour) time period, a relatively clean background condition, and low precipitation. Then, a two-week period was evaluated to characterize the persistence of wind-driven lake surface nanoparticle emissions on a regional scale. Cases will be simulated both with and without parameterized emissions of nanoparticles from the lake surface, and analysis will focus on the changes to the aerosol population on the regional scale. The study will conclude with a discussion of the potential impacts of the modeled changes to the aerosol population and of the model improvements needed to enable a more rigorous study of the impact of wind-generated aerosols on aerosol-cloud interactions.

\section{Method}

\subsection{WRF-Chem}

For the study we employed version 2.2 of the mesoscale Weather Research and Forecasting model with online Chemistry (WRF-Chem). The model is based on version 2 of the non-hydrostatic WRF community model, developed at the National Center for Atmospheric Research in collaboration with several other research institutions (http://www. wrf-model.org). WRF-Chem is an operational forecasting model that is designed to be computationally efficient and flexible for scientific research. One of the most advanced aspects of WRF-Chem is that its architecture allows for consistency between the chemical and meteorological modeling components such that they both use the same time step, horizontal and vertical resolutions, transport schemes, and physics schemes for subgrid-scale processes. This "online" feature within WRF-Chem allows for the study of aerosol-cloud-radiation-meteorology interactions and feedbacks (e.g., Gustafson et al., 2007; Ntelekos et al., 2009;
Zhang et al., 2010b; Zhao et al., 2010). The general performance of WRF-Chem has been well documented (e.g., McKeen et al., 2009; Zhao et al., 2010), including for the northeastern United States for the period used for this study (McKeen et al., 2007).

To accurately simulate all of the meteorological, chemi$\mathrm{cal}$, and aerosol processes over urban to regional scales that can affect aerosol-cloud-radiation interactions is still a challenge, despite the recent advances in incorporating aerosol dynamics models into three-dimensional regional and global models. Nevertheless, the actively supported community WRF-Chem model provides a useful tool for the systematic analysis of aerosol impacts on radiation and clouds and for evaluating our current understanding of aerosol formation and transformation processes in the atmosphere. For this initial investigation on the potential significance of lakesurface nanoparticles, we have not considered aerosol-cloudradiation interactions; instead, this study focuses on the impact wind-generated ultrafine particles from the Great Lakes on the aerosol number concentrations as a proxy for their potential impact on regional climate.

The meteorological dynamics and physics options included in WRF have been described by Skamarock et al. (2005). Unless otherwise noted, WRF physics options used for this study include the following: the Goddard shortwave radiation scheme (Chou and Suarez, 1994), the RRTM longwave radiation scheme (Mlawer et al., 1997), the Yonsei University (YSU) planetary boundary layer (PBL) scheme (Hong and Pan, 1996) coupled to the MM5 surface-layer scheme, the Noah land-surface model (Chen and Dudhia, 2001), the Grell-Devenyi cumulus cloud parameterization (Grell and Devenyi, 2002), and the WSM 5 microphysics scheme (Hong et al., 2004). For WRF-Chem, several modules for gas- and aerosol-phase chemistry and dynamics have been incorporated into WRF; a general description of WRFChem is provided by Grell et al. (2005), and the incorporation of the chemistry and aerosol modules used for this study is explained in Fast et al. (2006). Here, only the components of WRF-Chem relevant for this study will be discussed.

The WRF-Chem gas-phase chemistry and aerosol modules were used to simulate aerosol concentrations and size distributions for July 2004 in the eastern United States so that we could characterize the potential for particle emissions from the Great Lakes surface to impact the regional aerosol population. The gas-phase chemistry and aerosol modules employed for this study are the Carbon Bond Mechanism Z (CBM-Z) (Zaveri and Peters, 1999) and the Model for Simulation Aerosol Interactions and Chemistry (MOSAIC) (Zaveri et al., 2008), respectively. Both modules had been previously integrated into the WRF framework (Fast et al., 2006). This version of WRF-Chem with CBM-Z and MOSAIC includes inorganic aerosol components and primary organic and elemental carbon; secondary organic aerosol (SOA) is not included. 
To explicitly model the aerosol size distribution, the MOSAIC aerosol module in WRF-Chem uses a two-moment sectional approach in which concentrations of both aerosol number and mass are simulated prognostically for each bin so that total mass (gas + aerosol) and aerosol number are conserved simultaneously during condensation and evaporation. The MOSAIC aerosol module within WRF-Chem models particles with dry diameters between $40 \mathrm{~nm}$ and $10 \mu \mathrm{m}$, with the size range divided into either four or eight size bins. The option of eight size bins is chosen for this study, with the dry particle diameters doubling for each successive bin boundary. Within each bin, particles are assumed to be internally mixed and can be composed of sulfate, nitrate, ammonium, other (unspecified) inorganic material, primary organic carbon, elemental carbon, and water. Rates of condensation and evaporation for trace gases $\left(\mathrm{H}_{2} \mathrm{SO}_{4}, \mathrm{HNO}_{3}\right.$, and $\left.\mathrm{NH}_{3}\right)$ are based on particle size and equilibrium concentrations determined from the MTEM (Zaveri et al., 2005a) and MESA (Zaveri et al., 2005b) thermodynamics models. Once condensation/evaporation rates are calculated based on ambient concentrations and equilibrium vapor pressures, the transfer of particle mass and number between bins can be are computed using either the moving center algorithm of Jacobson (1997) or the two-moment algorithm of Simmel and Wurzler (2006) that is built on the method of Tzivion et al. (1989); the latter is used for this study. MOSAIC simulates Brownian coagulation using the method of Jacobson et al. (1994). For new particle formation, the model directly applies the $\mathrm{H}_{2} \mathrm{SO}_{4}-\mathrm{H}_{2} \mathrm{O}$ binary nucleation rate of Wexler et al. (1994) as the formation of rate of particles at the smallest diameter tracked by the model $(40 \mathrm{~nm})$, i.e., the model does not adjust for particle growth from molecular clusters to $40 \mathrm{~nm}$ or loss of sub-40nm particles due to coagulation with larger particles. When new particles form, $\mathrm{H}_{2} \mathrm{SO}_{4}$ is assumed to be completely neutralized by $\mathrm{NH}_{3}$ if a sufficient amount exists in the gas phase.

\subsection{Baseline emissions}

The emissions inventory used in this study was described by Kim et al. (2006). The portion of the inventory covering United States emissions was updated from the U.S. EPA NEI99 (National Emissions Inventory, base year 1999) versions 3 (http://www.epa.gov/ttn/chief/net/1999inventory. html\#final3.crit). Details of the NEI99 inventory and its implementation within WRF-Chem are discussed in detail by Frost et al. (2006). The emissions inventory was initially constructed to model a typical 1999 ozone-season day using data provided by the EPA. The updated inventory includes the reported point source emissions of $\mathrm{NO}_{\mathrm{x}}(64 \%$ of the total NEI99 $\mathrm{NO}_{\mathrm{x}}$ point emissions) and $\mathrm{SO}_{2}$ (80\% of NEI99 $\mathrm{SO}_{2}$ point emissions) from nearly 1000 individual monitoring locations within the Continuous Emissions Measurement System (CEMS) network for the summer of 2004. Emissions from point sources included in NEI99 but not in the CEMS dataset were kept at their 1999 levels. On-road, off- road, and area emissions from NEI99, as well as the point source emissions of compounds other than $\mathrm{NO}_{\mathrm{x}}$ and $\mathrm{SO}_{2}$, were not modified and remain at 1999 ozone season daytime levels. The revised inventory developed by Frost et al. (2006) also included the 1995 Canadian province- and census-division-level area and mobile emissions available from EPA (ftp://ftp.epa.gov:EmisInventory/canadaSMOKE) and the 1999 Mexican state-level area source emissions north of $24^{\circ} \mathrm{N}$ compiled for the BRAVO study (http://www.epa. gov/ttn/chief/net/mexico.html).

\subsection{Lake surface emissions}

At present, there are not enough data available to develop a parameterization for estimating the wind-driven particle emissions from freshwater lake surfaces; the measurements described by Slade et al. (2010) are insufficient. However, a reasonable approximation of the lake surface particle emissions rate can be drawn from marine particle number flux measurements. As has been described in detail by recent reviews of marine aerosol production (Lewis and Schwartz, 2004; O'Dowd and De Leeuw, 2007), the great majority of the particle number production from the ocean surface is due to the wind-driven entrainment and subsequent bursting of small air bubbles in breaking waves. The bursting of these bubbles result in the production of numerous small droplets from the rupture of the bubble film, and the ejection of a smaller number of somewhat larger droplets from a pressureinduced jet. After emission, droplets produced by either mechanism will rapidly equilibrate to the ambient relative humidity, resulting in a emissions spectra whose concentration is related chiefly to wind speed and whose size distribution is related chiefly to the concentration of trace species at the water surface.

While evidence suggests that the presence of surfaceactive organic species in the surface layer has some effect on wind-driven droplet production, to a first approximation the number of droplets produced from a freshwater surface should be very similar to the number produced from a marine surface. This is true even though the size distribution of the resultant equilibrated particles would be quite different from a freshwater lake due to the vastly different concentrations of dissolved material in saltwater and fresh water. If we assume that the droplet number production does not depend on the lake surface water composition, then we can model the dry particle number flux from the Great Lakes using the particle number flux parameterizations derived by Geever et al. (2005) for a marine environment:

$\log \left(F_{10 \mathrm{~nm}}\right)=0.099 U_{22}-0.73$

$\log \left(F_{100 \mathrm{~nm}}\right)=0.109 U_{22}-1.19$

Here, $U_{22}$ is the horizontal wind speed at $22 \mathrm{~m}$ (in $\mathrm{m} \mathrm{s}^{-1}$ ) and $F_{10 \mathrm{~nm}}$ and $F_{100 \mathrm{~nm}}$ are the particle source fluxes (in $10^{6} \mathrm{~m}^{-2} \mathrm{~s}^{-1}$ ) for particles with diameters larger than $10 \mathrm{~nm}$ 
and larger than $100 \mathrm{~nm}$, respectively. These parameterizations were based on measurements conducted at a coastal site at Mace Head, Ireland; they were consistent with previous measurements in the north Atlantic (Nilsson et al., 2001) and an earlier parameterization proposed by Mårtensson et al. (2003) (O'Dowd and De Leeuw, 2007). O'Dowd et al. (2008) recently suggested an updated parameterization for $F_{100 \mathrm{~nm}}$ based on the same data, but no complementary update is available for $F_{10 \mathrm{~nm}}$.

For this study we have used the $F_{10 \mathrm{~nm}}$ parameterization developed by Geever et al. (2005) (Eq. 1) to describe the dry particle number emissions flux from the Great Lakes. We chose to use the $F_{10 \mathrm{~nm}}$ parameterization rather then the one for $F_{100 \mathrm{~nm}}$ with the assumption that the former estimate best represents the total number of wind-driven droplets released by the water surface. From that we decided that $F_{10 \mathrm{~nm}}$ is a better upper bound estimate of the total number flux of particles from the surface after water vapor equilibration and is therefore optimal for evaluating the maximum potential contribution of lake-derived aerosols. Because the smallest particle size bin in the model is $40-80 \mathrm{~nm}$, we assume that predicted $F_{10 \mathrm{~nm}}$ number flux is emitted entirely into the 40 $80 \mathrm{~nm}$ size bin. The potential implications of this assumption will be discussed in Sect. 4. The composition of the emitted particles are based on the composition of lake surface water (Table S1 of Slade et al., 2010), except that we reclassify the measured $\mathrm{Mg}^{2+}$ and $\mathrm{Ca}^{2+}$ as $\mathrm{Na}^{+}$because the WRFChem does not include former two ions. Sensitivity simulations using different emitted particle compositions indicate that the results are not sensitive to this assumption (results not shown).

The $F_{10 \mathrm{~nm}}$ parameterization (Eq. 1) requires $22-\mathrm{m}$ horizontal wind speed, which is not a standard diagnostic parameter within WRF-Chem. For this study, wind speeds at $22 \mathrm{~m}$ have been calculated using modeled surface-level wind speeds and Monin-Obukhov similarity theory with the same stability functions as those used in WRF's 10-m wind field calculations. In WRF, different surface-layer schemes use different stability functions. The reader is referred to Skamarock et al. (2005) and references therein for details on the stability functions used in the surface-layer schemes (MM5 and Eta) applied in this study.

\subsection{Simulations}

The goal of this study is to characterize the potential for lakederived particles to impact the regional aerosol population. These potential impacts can be evaluated both on short timescales after a meteorological "event" and by examining the average impacts over longer time periods. The greatest shortterm impacts should occur when two meteorological conditions are met: (1) the presence of high winds over the lake surface, which would lead to the most intense lake surface emissions; and (2) the absence or low level precipitation in the region, which would minimize the effectiveness of wet deposition as a removal mechanism for the freshly-emitted particles. To find a suitable case that met these conditions, we revisited a set of 24-h retrospective simulations that had been performed for 12-31 July 2004 for a domain covering the eastern United States at $27-\mathrm{km} \times 27-\mathrm{km}$ horizontal resolution with 34 vertical layers (Fig. 1a) (McKeen et al., 2007). These simulations were initialized at 00:00:00 UTC each day with National Centers for Environmental Prediction (NCEP) Global Forecast System (GFS) model analysis fields. The WRF results from these existing simulations were reanalyzed for a sub-domain that included most of the Great Lakes region (Fig. 1b). Lake Ontario was not included in the analysis domain because of its small size relative to the northern Great Lakes and because it is more heavily influenced by anthropogenic sources, suggesting that the impact of lake aerosols would be small. In our reanalysis 14 July 2004 emerged as a suitable test case- on this day there was an extended period of strong surface winds over the northern Great Lakes, especially Lake Huron, and limited regional precipitation (Fig. 2). Moreover, the wind event on July 14 was relatively isolated- winds were calmer on the preceding and following days which allowed to more easily focus on the impacts of the event for analysis.

Several sets of simulations were performed, with three cases for each set labeled DEFAULT, BASE, and LAKE (Table 1). The DEFAULT cases use the emissions parameterizations already included in version 2.2 of WRF-Chem and that are still used in the most recent publicly released version of the model (version 3.3). Prior to version 3.0, the WRF model did not distinguish between ocean and freshwater bodies; instead, WRF-Chem assumes all non-land grid cells are over oceans and thus in our DEFAULT cases all water surfaces are treated as if they were ocean. As a result, in the DEFAULT cases the Great Lakes are emissions sources for large sea-salt particles based on the parameterization of Gong et al. (1997). (In version 3.0 and later, there is a nondefault option in WRF that distinguishes between ocean and inland water bodies; however, WRF-Chem does not make use of this new land-use category and thus still treats all non-land grid cells as oceans.) For the BASE cases, WRFChem was modified so that there are no emissions from the lakes whatsoever by turning the sea-salt parameterization for the Great Lakes sub-domain off in the model (any sea-salt emissions from the Atlantic Ocean were unaffected). In the LAKE cases, ultrafine-particle emissions from the surface of the Great Lakes were estimated using the $F_{10 \mathrm{~nm}}$ parameterization developed by Geever et al. (2005) (Eq. 1). All particles emitted from the lake surface were assumed to have dry diameters of $40 \mathrm{~nm}$ and were initially placed in the smallest of the eight size bins included in the MOSAIC aerosol dynamics module in WRF-Chem. This approximation implicitly assumes that the emitted particles are somewhat larger than what was observed by Slade et al. (2010), but this simplification is not expected to significantly impact the aerosol number concentration results. 
Table 1. Summary of WRF-Chem simulations performed.

\begin{tabular}{|c|c|c|c|c|}
\hline Simulation & $\begin{array}{l}\text { Emissions } \\
\text { over Lakes }\end{array}$ & $\begin{array}{l}\text { Aerosol } \\
\text { Processes }\end{array}$ & PBL Scheme & Period* \\
\hline DEFAULT0 & Sea-salt & All & YSU & 14-27 July 2004 \\
\hline BASE0 & None & & & 14-27 July 2004 \\
\hline LAKE0 & Ultrafine & & & 14-27 July 2004 \\
\hline DEFAULT1 & Sea-salt & Nucleation & YSU & 14-27 July 2004 \\
\hline BASE1 & None & Off & & 14 July 2004 \\
\hline LAKE1 & Ultrafine & & & 14 July 2004 \\
\hline DEFAULT2 & Sea-salt & Coagulation Off & YSU & 14 July 2004 \\
\hline BASE2 & None & \& Dry Deposition Off & & 14 July 2004 \\
\hline LAKE2 & Ultrafine & & & 14 July 2004 \\
\hline BASE3 & None & All & MYJ & 14 July 2004 \\
\hline LAKE3 & Ultrafine & & & 14 July 2004 \\
\hline
\end{tabular}

* 12-13 July 2004 BASE-case simulations are used as chemical spin-up for each set.

(a) WRF-Chem Simulation Domain

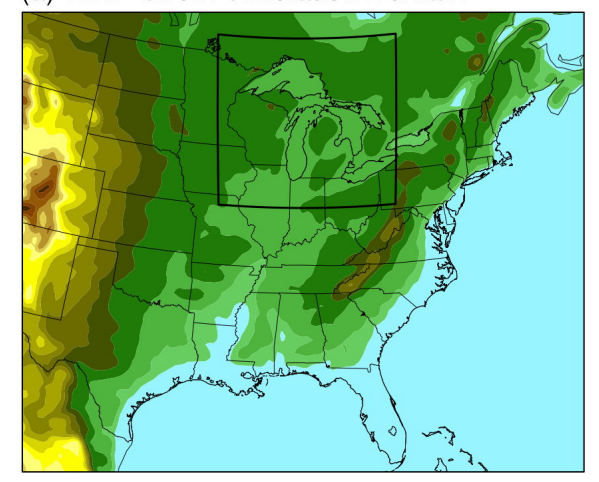

\section{(b) Analysis Domain}

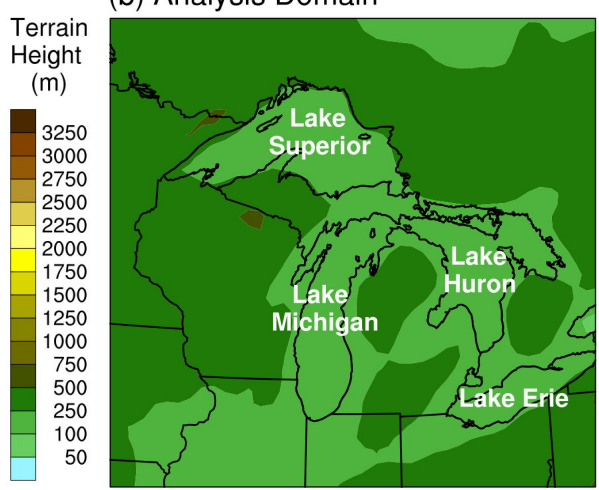

Fig. 1. (a) Terrain height (m) of the WRF-Chem simulation domain and (b) analysis domain focusing on the Great Lakes region.

The DEFAULT, BASE, and LAKE cases were repeated with several combinations of aerosol dynamics processes (nucleation, coagulation, and dry deposition) turned on and off in order to determine the sensitivity of the results to other processes affecting aerosol number concentration. Among the physics options available in WRF, the choice of planetary boundary layer (PBL) scheme has the greatest potential to impact the results because it affects modeled wind speeds, which determine the emission rates of lake aerosols, and PBL height, which impacts the vertical mixing of emitted particles. For this reason, simulations were also performed using the Mellor-Yamada-Janjic (MYJ) (Mellor and Yamada, 1982; Janjic, 2002) instead of the YSU PBL scheme; this change in the PBL scheme also requires replacing the MM5 surface-layer scheme with the Eta surfacelayer scheme. Most WRF-Chem simulations were conducted for 14 July 2004 only, to investigate the short-term impact of lake aerosols (with 12-13 July simulations of the BASE cases used for model spin-up). Some of the simula- tions were extended to 27 July to investigate the longer-term average impacts.

\section{Results}

\subsection{Episodic impacts on 14 July 2004}

14 July 2004 was chosen for the episodic event study because the WRF model results for that day meet the two criteria that were presumed necessary for the lake surface source to contribute significantly to the aerosol population- high surface wind speeds and the absence or near absence of precipitation over and downwind of the Great Lakes. Figure 2 shows the modeled 22-m wind speed and aerosol number flux, with wind vector overlays, for 14 July 2004 at 12:00:00 GMT (08:00 a.m. Eastern Daylight Time). This was the time of highest modeled wind speeds during this day. The results indicate that during this period winds were generally northerly 
(a) 22-meter Wind Speed

2004-07-14_12:00:00 GMT

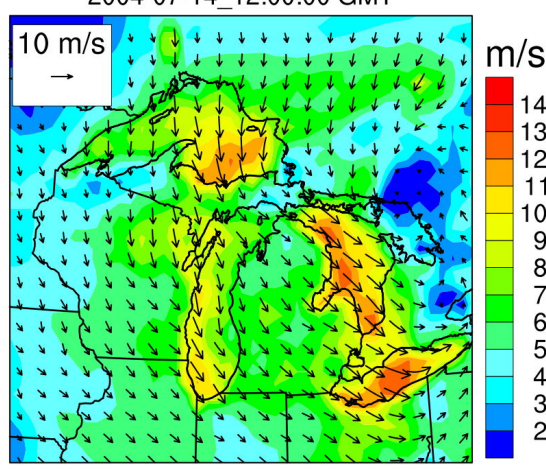

(b) Lake Aerosol Number Flux 2004-07-14 12:00:00 GMT

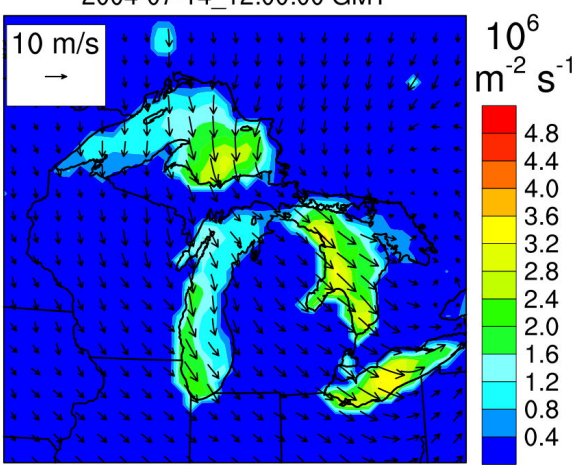

Fig. 2. Results for 12:00:00 GMT ( 8 am Eastern Daylight Time) on 14 July 2004: (a) 22-m wind speed (m s ${ }^{-1}$ ), and (b) wind-generated aerosol number flux $\left(10^{6} \mathrm{~m}^{-2} \mathrm{~s}^{-1}\right)$ over the lakes using the parameterization of Geever et al. (2005) (see Sect. 2.3 text), with wind vector overlay.

(a) $N_{L=1, \text { BASE0 }}$

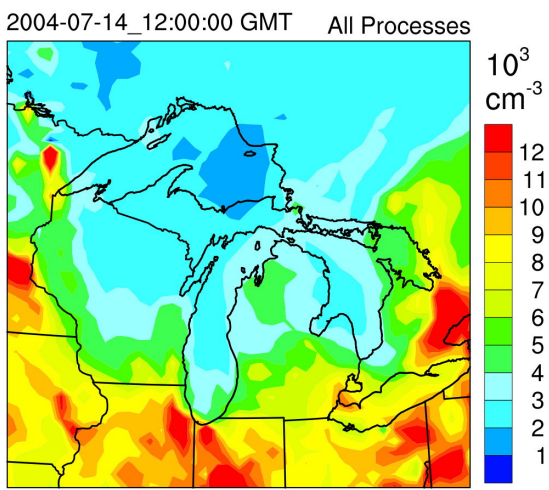

(b) $\Delta N_{L=1, \text { LAKEO - BASE0 }}$

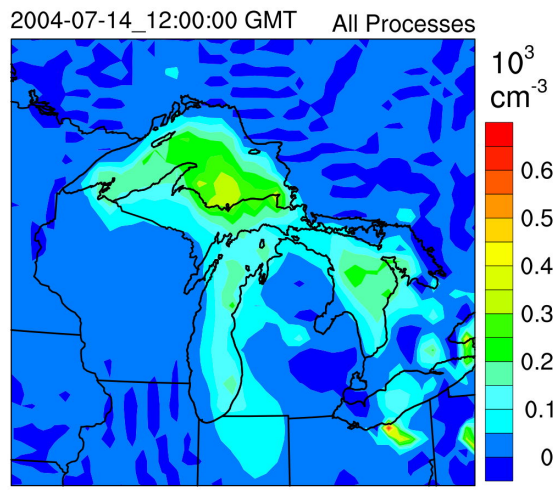

(c) $\% \Delta N_{L=1, \text { LAKEO - BASEO }}$

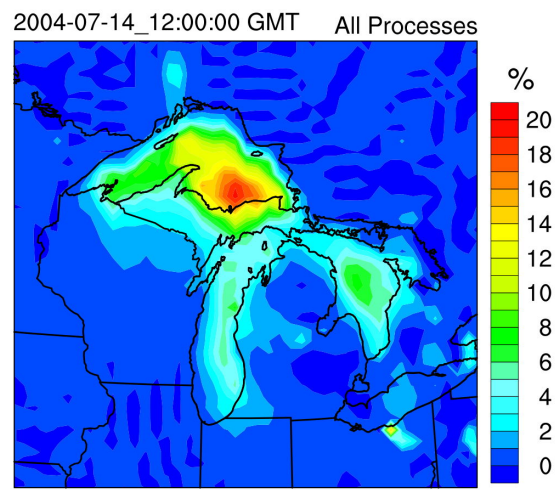

Fig. 3. Simulation results for 12:00:00 GMT ( 8 am Eastern Daylight Time) on 14 July 2004 with all aerosol dynamical processes included: (a) surface-layer aerosol number concentrations $\left(10^{3} \mathrm{~cm}^{-3}\right)$ for the BASE0 case, (b) difference between LAKE0 and BASE0 cases, and (c) percent difference between LAKE0 and BASE0 cases.

to northwesterly over most of the Great Lakes region except for over Lake Erie, where the winds were turning southeasterly. Wind speeds were greater than $8 \mathrm{~m} \mathrm{~s}^{-1}$ over most of the Great Lakes and greater than $15 \mathrm{~m} \mathrm{~s}^{-1}$ over Lake Huron (Fig. 2a). These wind speeds led to particles being emitted from the lake surface at rates on the order of a few $10^{6} \mathrm{~m}^{-2} \mathrm{~s}^{-1}$. The areas of greatest particle emissions during the 14 July 2004 event were the southeast part of Lake Superior, western Lake Huron, and over Lake Erie (Fig. 2b).

Figure 3 shows the surface-layer aerosol number concentrations and the difference and percent difference between the LAKE0 and BASE0 cases for 14 July 2004 at 12:00:00 GMT- the same time as is represented in Fig. 2. The results shown in Fig. 3 are based on simulations with atmospheric new particle formation, coagulation, and dry deposition processes all active in the model. The spatial distribution of aerosol number concentrations shown in Fig. 3a indicates that contributions to aerosol number concentrations within the analysis domain were dominated by urban and industrial emissions from Chicago, Detroit, and the Ohio River Valley region. Because the prevailing winds are northerly to northwesterly, most of the Great Lakes region was upwind of the major emissions sources during this period, with the exception of Lake Erie where surface level concentrations were $\sim 8000 \mathrm{~cm}^{-3}$. Air over Lake Superior was the most pristine among all the Great Lakes, as expected since it is also the most remote. Concentrations over Lake Superior were generally less than $\sim 2000 \mathrm{~cm}^{-3}$ in the BASE0 case. Concentrations over Lakes Michigan and Huron were generally between $\sim 2000$ and $\sim 4000 \mathrm{~cm}^{-3}$.

Figure $3 \mathrm{c}$ shows relative increases in surface-level aerosol concentrations when wind-generated emissions from the lake surface are included in the model. The percentage change was greatest over southeastern Lake Superior, where the 
(a) $\% \Delta N_{L=1, \text { LAKEO - BASEO }}$

\section{(b) Time Series on 2004-07-14}
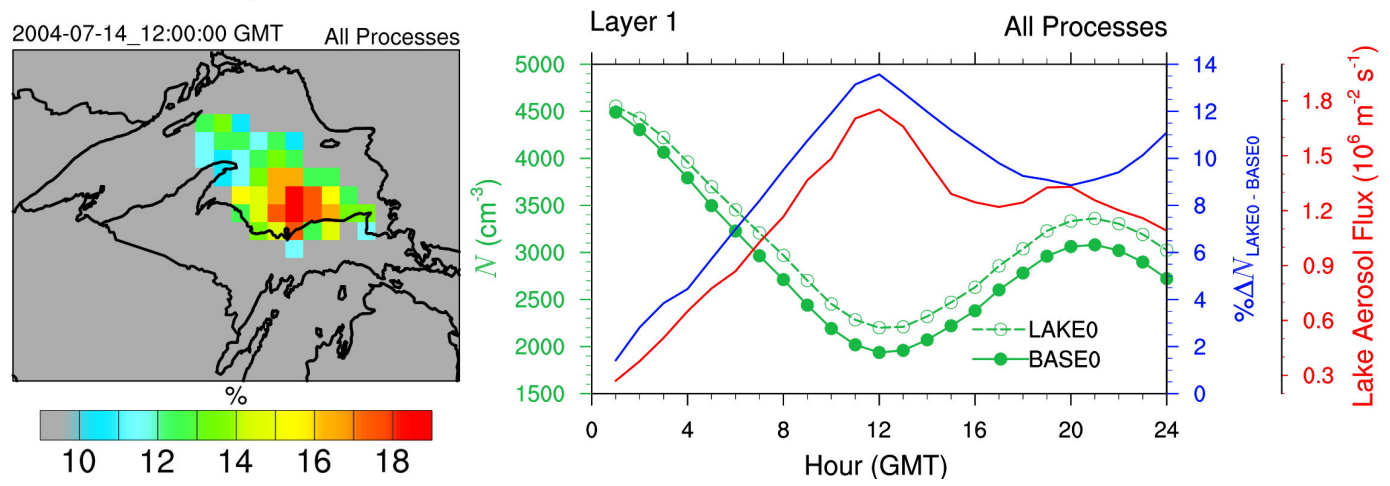

Fig. 4. (a) Same as Fig. 3c but focusing on the Lake Superior region and highlighting grid cells in which the percent difference is greater than 10\%; (b) hourly results for 4 July 2004 for the region highlighted in (a). Results shown include the total surface-layer aerosol number concentration $N$ for BASE0 and LAKE0, the percent difference between them when all aerosol dynamical processes are included, and wind-generated lake surface aerosol number flux.

lake emissions increased the surface layer concentrations by $\sim 20 \%$. This large percentage increase resulted from a combination of a relatively high lake surface emissions rate and a very low pre-existing aerosol concentration. Lake surface aerosol emission rates were actually slightly higher over Lakes Erie and Huron than over Lake Superior (Fig. 2b), but because of the higher relative amounts of pre-existing aerosol in those regions, the percentage increases over the former lakes were less than $\sim 8 \%$ and $\sim 4 \%$, respectively, even though the absolute increase is similar (Fig. 3b) The results in Fig. $3 \mathrm{~b}$ and $\mathrm{c}$ also suggest that the impacts of the lake surface aerosol emissions are located predominantly within the source region. Percentage increases in aerosol concentrations over land downwind of the Great Lakes were generally smaller than $2 \%$ and persisted for only $\sim 100 \mathrm{~km}$; the exception to this result was over Michigan's Upper Peninsula where surface-layer aerosol enhancement was 6-14\% for much of the area between Lakes Superior and Michigan.

The relationship between the lake surface aerosol flux and the surface-layer aerosol concentration can be better understood by looking at their temporal relationship. For simplicity we will focus this comparison on the region with the greatest relative increase in aerosol concentration- the southeast part of Lake Superior. Figure 4a shows the area of comparison- those grid cells over and adjacent to Lake Superior where the percentage difference between the LAKE0 and BASE0 cases at 12:00:00 GMT on 14 July 2004 was greater than $10 \%$. Time series of the surface-layer aerosol number concentrations for the two cases, the percentage difference between them, and lake surface aerosol number fluxes are shown for this area in Figure 4b. On this day, the wind speeds increased continuously from 0 to $12 \mathrm{GMT}$; as the winds picked up, the aerosol number concentrations decreased in the BASE0 case as dilution occurred. The same temporal trend was predicted in the case for which lake surface aerosol emissions were included in the model (the LAKE0 case), but in the latter case the rate of decrease in aerosol concentration was smaller. Both cases had an average surface layer concentration of $\sim 4500 \mathrm{~cm}^{-3}$ at 0:00 GMT, but by the 12:00 GMT minimum the LAKE0 average concentration was $\sim 200-300$ particle per $\mathrm{cm}^{3}$ greater than the BASE0 case $\left(\sim 2500 \mathrm{~cm}^{-3}\right.$ and $\sim 2000 \mathrm{~cm}^{-3}$ for the LAKE0 and BASE0 cases, respectively). In general, the percent contribution increase of lake surface-derived aerosols was more strongly correlated with the changing background particle concentration rather than increased lake surface emissions from the increased wind speed.

New particle formation, defined here as nucleated particles that have grown to the smallest size tracked by the model, is usually not a significant source of aerosol number over regions of high pre-existing aerosol loading; in those circumstances the competition for condensable material favors condensation onto pre-existing particles. However, in more pristine environments new particle formation events can be common when the concentrations of precursor gases are sufficiently high. In many regions atmospheric new particle formation can be the dominant mechanism for increasing the particle number concentration. This appears to be true in the model for the northern Great Lakes region- a comparison of the BASE case with nucleation turned on (BASE0, Fig. 3a) and off (BASE1, Fig. 5a) indicates that surface-layer aerosol number concentrations were 3-4 times higher over most of Lake Superior in the model when nucleation was active. For Lakes Michigan, Huron, and Erie, aerosol number was reduced by $\sim 50 \%$ when atmospheric new particle formation was turned off in the model. Without new particle formation, the percent increase in surface layer aerosol number concentration would have been up to $\sim 200 \%$ over Lake Superior and as high as $40 \%$ over Lakes Michigan and Huron (Fig. 5c). This implies that the importance of the lake surface 
(a) $N_{L=1, \text { BASE } 1}$

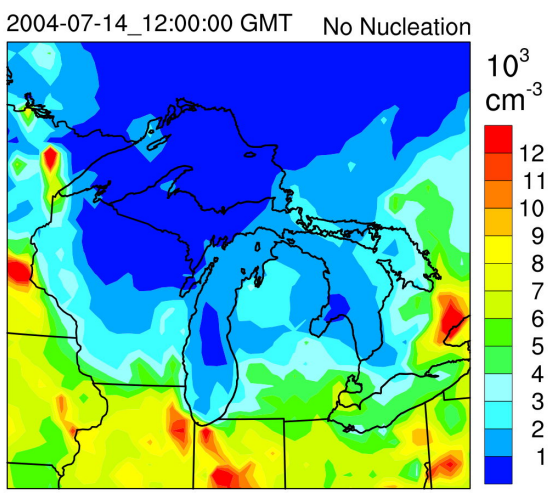

(b) $\Delta N_{L=1, \text { LAKE1 - BASE1 }}$

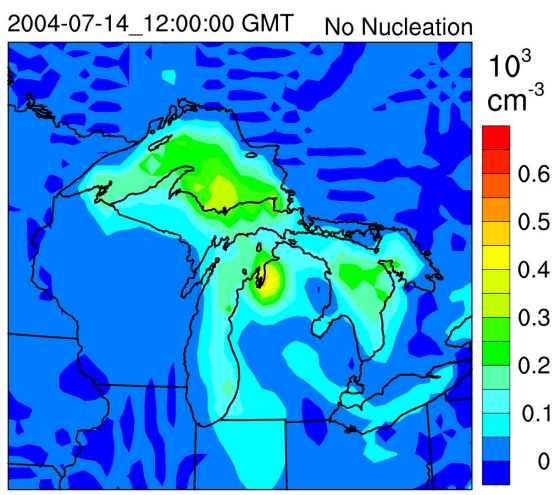

(c) $\% \Delta N_{L=1, \text { LAKE1 - BASE1 }}$

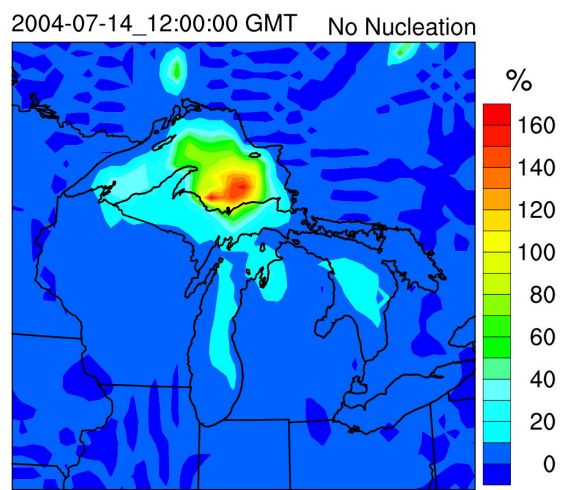

Fig. 5. Same as Fig. 3 except results are based on simulations with new particle formation turned off in the model.

(a) $\% \Delta N_{\text {column, } L=1-6, \text { LAKE - BASE }}$

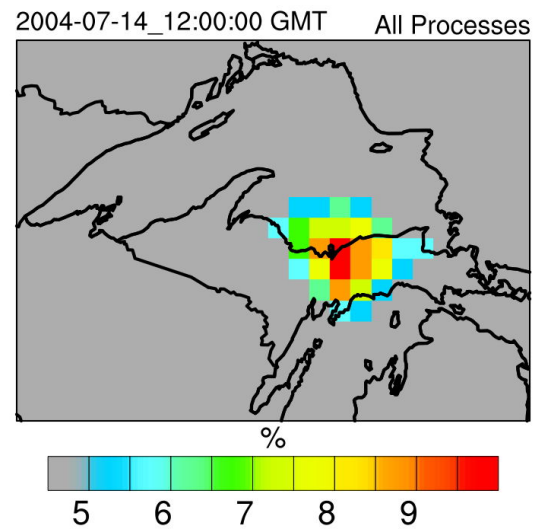

(b) Vertical Profiles

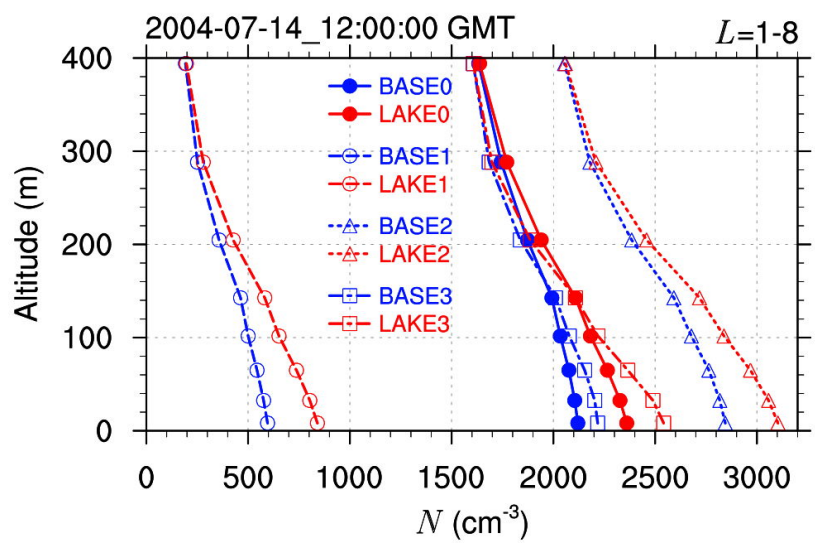

Fig. 6. Results at 12:00:00 GMT on 14 July 2004: (a) percent difference in column aerosol number burden summed over the lowest six model layers between the LAKE0 and BASE0 cases when all aerosol dynamical processes are included in the model; (b) vertical profiles of aerosol number for the lowest eight model layers and for the grid cells highlighted in (a).

emissions in the region is highly sensitive to the strength and frequency of new particle formation events in the region (and to the accuracy of the model in representing those events).

In addition to the surface-layer results, column burdens and vertical profiles of aerosol number were also examined to determine whether lake surface aerosol emissions could have significant impacts on aerosol number concentrations above the surface layer. Figure 6a shows the percent difference in aerosol column burdens between the LAKE0 and BASE0 cases; this comparison includes the six lowest layers in the model, from the surface up to $\sim 200 \mathrm{~m}$. The maximum difference in column burden was $\sim 10 \%$, and occurred slightly downwind of Lake Superior along the southeastern shore. Comparing Figs. 4a and 6a suggests that while the percentage increase in aerosol loading was greatest in the surface layer, the impact of lake surface aerosol emissions was carried further downwind above the surface layer. Fig- ure $6 \mathrm{~b}$ shows the vertical profiles of the aerosol number concentrations averaged over the grid cells highlighted in Fig. 6a (i.e., the grid cells in which the percent difference between the LAKE0 and BASE0 cases was greater than $5 \%$ ). These vertical profiles indicate that the impact of lake aerosols decreased quickly with increasing altitude and was confined to only the $\sim 200 \mathrm{~m}$ closest to the surface. Although our modeling period is different than that of Slade et al. (2010), our model results are qualitatively consistent with their observations; Fig. 2 of Slade et al. (2010) indicates that particle enhancements over the lake were $\sim 300 \mathrm{~cm}^{-3}$ at altitudes of $\sim 200 \mathrm{~m}$, when the surface wind was $\sim 5 \mathrm{~m} \mathrm{~s}^{-1}$. Figure $6 \mathrm{~b}$ here suggests enhancements of $\sim 100 \mathrm{~cm}^{-3}$ at an altitude of $200 \mathrm{~m}$ when $22-\mathrm{m}$ winds were $\sim 10 \mathrm{~m} \mathrm{~s}^{-1}$. Figure $6 \mathrm{~b}$ also illustrates the impact of nucleation (BASE1 and LAKE1) and coagulation plus dry deposition (BASE2 and LAKE2) on the aerosol vertical profiles in the model as well as the impact 


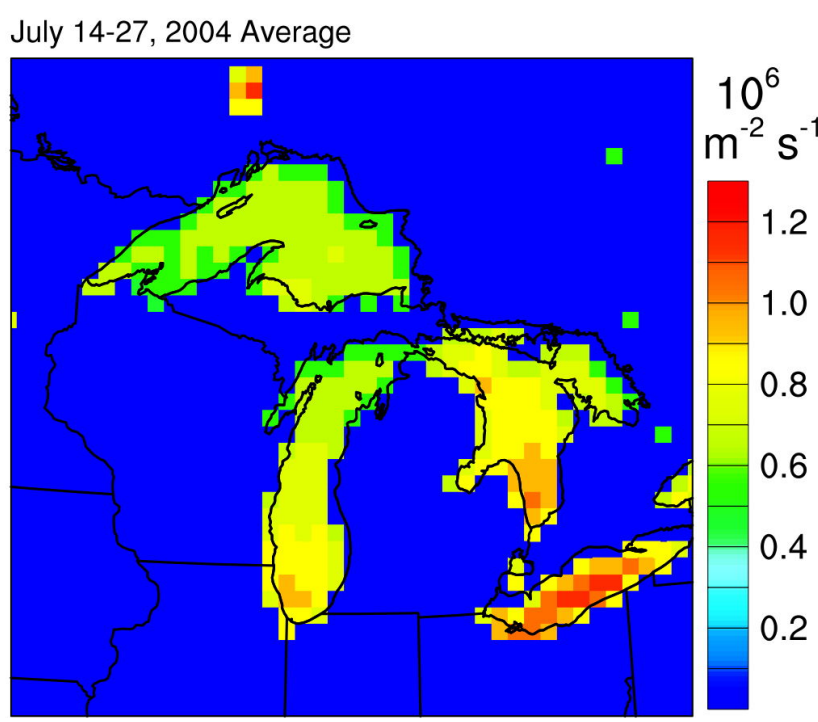

Fig. 7. Simulation results averaged over the 14-27 July 2004 twoweek period: wind-generated aerosol number flux $\left(10^{6} \mathrm{~m}^{-2} \mathrm{~s}^{-1}\right)$ over the Great Lakes region.

when the YSU PBL scheme is replaced with the MYJ PBL scheme (BASE3 and LAKE3). As was noted for the surfacelevel figures, new particle formation was the dominant source of particles in this region for the model period. Without new particle formation, the impact of lake surface aerosol emissions would be much greater on a percentage basis. On the other hand, without coagulation and dry deposition the preexisting (BASE2) aerosol number concentrations would increase and thus the impact of lake-derived aerosol becomes smaller on a percentage basis. The results were similar when the MYJ PBL scheme was used rather than the YSU PBL scheme.

\subsection{Averaged impacts for 14-27 July 2004}

Averaged simulations results for the two-week period of 1427 July 2004 for the cases with all aerosol processes included in the model are shown in Figs. 7 and 8. Figure 7 shows the time-averaged lake surface aerosol emissions rate based on the modeled 22-m wind speed and the parameterization of Geever et al. (2005) (Eq. 1). The time-averaged emission rate for the two-week period in mid-summer was on the order of $10^{6} \mathrm{~m}^{-2} \mathrm{~s}^{-1}$, with the highest values over Lake Erie $\left(\sim 1 \times 10^{6} \mathrm{~m}^{-2} \mathrm{~s}^{-1}\right)$ and the lowest over Lake Superior $\left(\sim 6 \times 10^{5} \mathrm{~m}^{-2} \mathrm{~s}^{-1}\right)$. Figure 8 a shows the two-week average of aerosol number concentration for the BASE0 case; Fig. $8 \mathrm{~b}$ and $\mathrm{c}$ show the difference and the percent difference, respectively, between the LAKE0 and BASE0 cases. As was seen for the 14 July 2004 episodic case, the greatest relative impacts from the lake surface aerosol emissions occurred over Lake Superior, even though emission rates were higher over the other Great Lakes. Aerosol number concentrations increased by $\sim 8 \%$ over central Lake Superior when lake aerosol emission is included, by $\sim 5 \%$ over Lake Huron and northern Lake Michigan, and by less than $2 \%$ over southern Lake Michigan and Lake Erie.

\section{3 "Freshwater Oceans"- standard WRF-Chem emissions}

As discussed in Sect. 2.4, WRF does not distinguish between ocean and freshwater lake water bodies, and so the publicly released versions of WRF-Chem (including the most recent release, version 3.3) treat all non-land surfaces as if they were oceans. Thus in standard WRF-Chem the Great Lakes are emissions sources for large sea-salt particles; specifically, the parameterization of Gong et al. (1997) is used to model seasalt emissions and is applied identically to both oceans and any other water bodies large enough to appear in the model grid. Several DEFAULT simulations (Table 1) were carried out that left this obvious error in place to investigate how this simplification impacted the aerosol population dynamics within the model.

For most of the simulation results, having sea-salt particles emitted over the Great Lakes introduced only small differences in aerosol number concentrations, but there were exceptions. Figure 9 illustrates how the erroneous introduction of sea-salt emissions from the Great Lakes can cause a significant modeling error. Figure 9a shows the percent difference in surface-layer aerosol number concentrations between the DEFAULT0 and BASE0 cases for 14 July 2004 at 20:00:00 GMT. Here, the inclusion of sea-salt emissions over the Great Lakes has resulted in an overall decrease in total aerosol number concentrations. This seemingly counterintuitive result can be explained by the fact that the presence of large sea-salt particles in the aerosol population can greatly increase the aerosol condensational sink, leading to reduced atmospheric new particle formation rates and hence a net decrease in the total number of particles even though there is an increase in primary emissions. This link between the emission of sea-salt particles over the Great Lakes and the suppression of new particle formation is confirmed in Fig. 9b, which shows that when new particle formation was turned off in the model, sea-salt emissions over the Great Lakes led to the more expected result of increased aerosol number concentrations (Fig. 9b). These results highlight the non-linearity of aerosol dynamics and the importance of including all sources of aerosol particles in the model correctly in order to model aerosol number (and hence $\mathrm{CCN}$ ) concentrations properly. Averaged over the 14-27 July 2004 period, the impact of erroneously introducing sea-salt particles over the Great Lake regions was to reduce surface-level aerosol number concentrations by $\sim 1 \%$ over Lake Huron; impacts over other regions were minimal when time-averaged over this two-week period (Fig. 10). 
(a) $N_{L=1, \text { BASE0 }}$

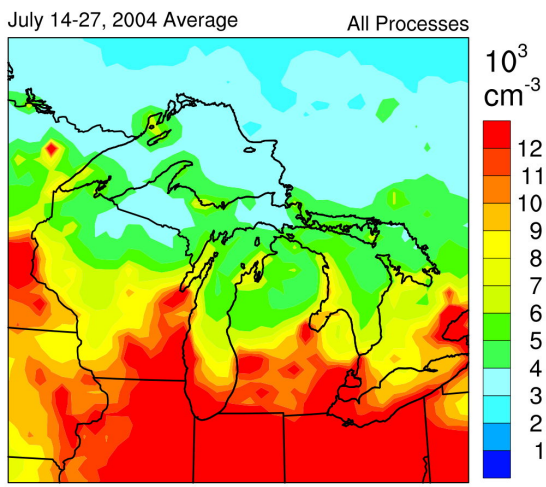

(b) $\Delta N_{L=1, \text { LAKEO - BASE } 0}$

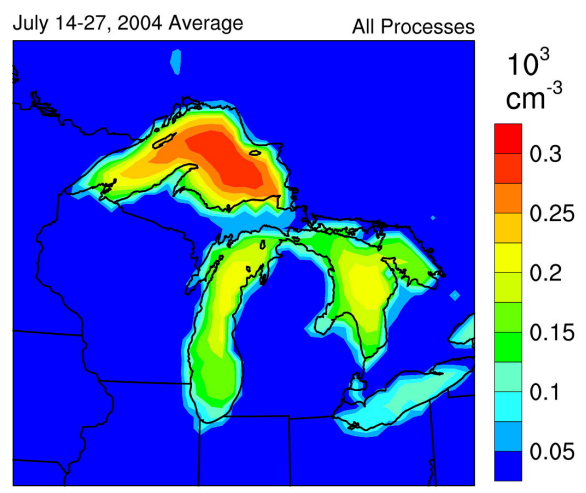

(c) $\% \Delta N_{L=1, \text { LAKEO - BASE } 0}$

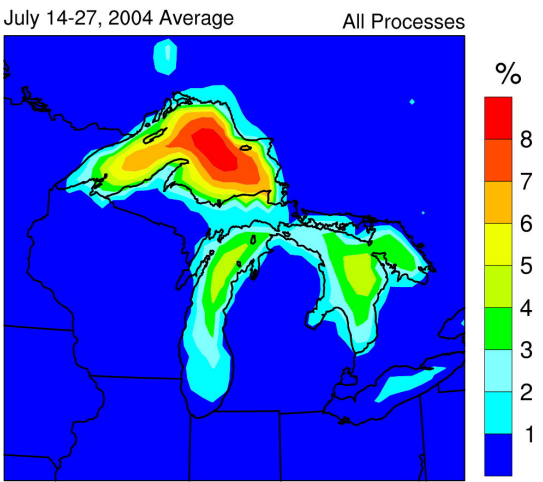

Fig. 8. Simulation results averaged over the 14-27 July 2004 two-week period with all aerosol dynamical processes included: (a) surfacelayer aerosol number concentration $\left(10^{3} \mathrm{~cm}^{-3}\right)$ for the BASE0 case, (b) difference between LAKE0 and BASE0 cases, and (c) percent difference between LAKE0 and BASE0 cases.

(a) $\% \Delta N_{L=1, \text { DEFAULTO - BASE0 }}$

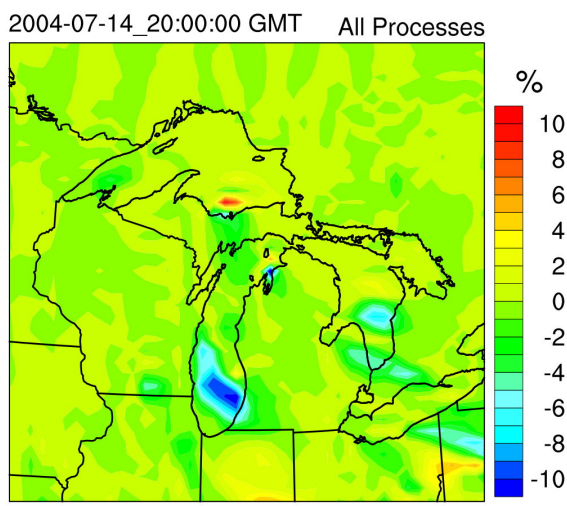

(b) $\% \Delta N_{L=1, \text { DEFAULT1 - BASE1 }}$

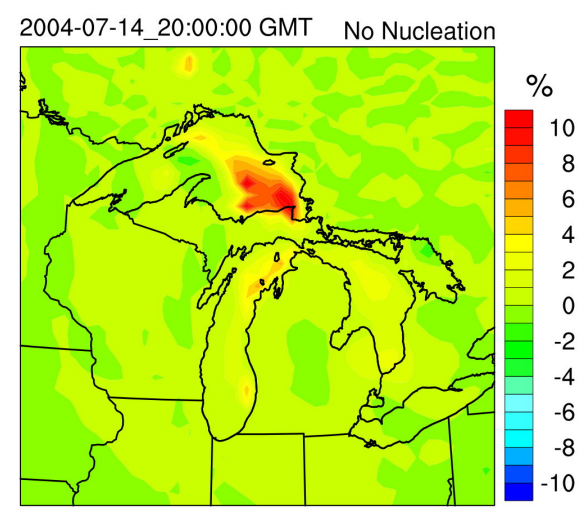

Fig. 9. Percent difference in surface-layer aerosol number concentrations between the DEFAULT and BASE cases for 20:00:00 GMT on 14 July 2004: (a) with all aerosol dynamical processes included in the model, and (b) with nucleation turned off in the model.

\section{Discussion}

This is the first modeling studying to investigate the potential impact of lake surface aerosol emissions on regional aerosol number concentrations over the Great Lakes region. The simulation results suggest that these wind-generated aerosol emissions can have significant impacts on number concentrations over the source region at least on an episodic basis, and potentially over longer timescales. However, there are significant uncertainties associated with emissions rate of lake aerosols, new particle formation rates, and several other model limitations. Even though the results here suggest that the impacts of the lake emissions on aerosol number concentrations exist largely within the source regions, the consequent effects of these sources on aerosol-cloud interactions could potential impact meteorology downwind of the Great Lakes by changing the CCN distributions and cloud formation and propagation. To understand whether and how strongly these emissions would have an impact on regional meteorology, additional modeling work is needed using a fully coupled aerosol-cloud regional meteorology model. While the most recent publicly-released version of WRFChem (version 3.3) is able to model aerosol-cloud interactions, considerable additional improvement is still needed in the modeling of aerosol size distributions for us to have confidence in the results.

The first required improvement would be to extend the modeled aerosol size bin to below the current minimum diameter of $40 \mathrm{~nm}$. Slade et al. (2010) found that the lakederived aerosols exist primarily in the $15-40 \mathrm{~nm}$ diameter size range, and it was a significant assumption in this work to place the lake surface aerosol emissions in the $40-80 \mathrm{~nm}$ size bin. Newly formed particles from atmospheric nucleation are likewise placed in this $40-80 \mathrm{~nm}$ bin immediately upon formation. The inclusion of smaller particles in the modeled size distribution would mean faster coagulation rates with 
(a) $\Delta N_{L=1, \text { DEFAULTO - BASEO }}$

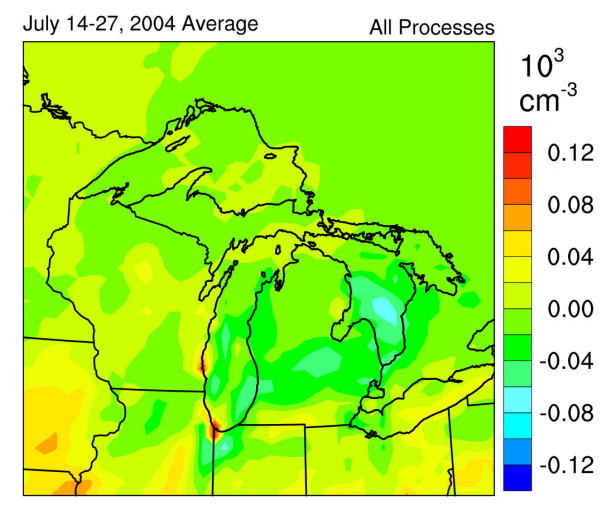

(b) $\% \Delta N_{L=1, \text { DEFAULTO - BASEO }}$

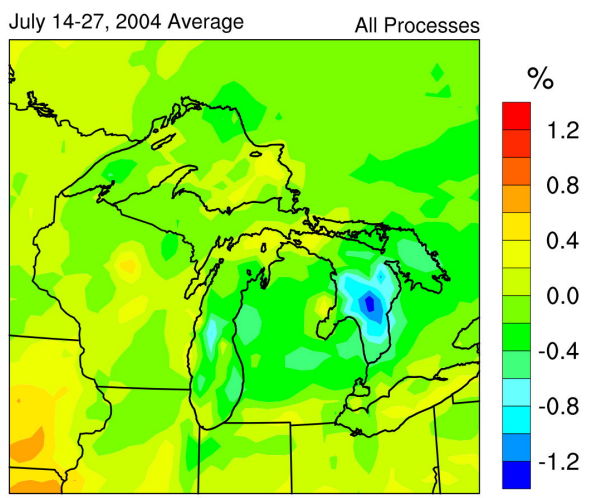

Fig. 10. (a) Difference and (b) percent difference in surface-layer aerosol number concentration between the DEFAULT0 and the BASE0 cases; results are averaged over the 14-27 July 2004 period.

larger particles, resulting in fewer particles overall. Particles with $D_{p}<40 \mathrm{~nm}$ also have faster dry deposition velocities than particles with $D_{p}=40 \mathrm{~nm}$ over water surfaces (Seinfeld and Pandis, 2006). Thus, assuming the emitted particles to be larger leads to aerosol number concentrations being slightly overestimated. Furthermore, properly modeling the size distribution is critical for determining $\mathrm{CCN}$ concentrations smaller particles are less likely to grow large enough to be $\mathrm{CCN}$. The specified size of the lake-derived particles will also affect the condensational sink, and thereby impact the dynamics of nucleation and condensational growth, which also has the potential to affect $\mathrm{CCN}$ concentrations.

A second needed improvement in the modeling of aerosol size distributions is in the parameterization of the new particle formation rate. The different parameterizations used in 3-D models can result in predicted new particle formation rates that span several orders of magnitude; this is a major source of uncertainty when estimating indirect radiative forcing and modeling aerosol-cloud interactions (Pierce and Adams, 2009; Zhang et al., 2010a, b). This study also highlights the need for accurate new particle formation parameterizations, since our simulation results suggest that new particle formation is the dominant source of particle number in the northern Great Lakes region and is the single most critical factor in determining the relative importance of the lake surface emissions source in determining the surface level aerosol concentration. As discussed earlier, the MOSAIC aerosol module in WRF-Chem applies the $\mathrm{H}_{2} \mathrm{SO}_{4}$ $\mathrm{H}_{2} \mathrm{O}$ binary homogeneous nucleation scheme of Wexler et al. (1994). Ambient measurements have suggested that binary nucleation theory underestimate observed nucleation rates (e.g., Weber et al., 1999), but these results are not conclusive for all regions. Zhang et al. (2010a) indicate the binary nucleation of Wexler et al. (1994) exceeds the upper limit of dimer formation rate under some ambient conditions. Another weakness of the model used is that it equates the $\mathrm{H}_{2} \mathrm{SO}_{4}-\mathrm{H}_{2} \mathrm{O}$ binary homogeneous nucleation rate to new particle formation rate at $D_{p}=40 \mathrm{~nm}$ without adjusting for the growth of nucleated clusters to $D_{p}=40 \mathrm{~nm}$. The effect of ignoring this process is difficult to predict: it may overestimate new particle formation rate by not accounting for particle losses by coagulation and dry deposition for particles smaller than $D_{p}=40 \mathrm{~nm}$, but it could also potentially lead to underestimates due to overpredicting the condensational sink and thereby reducing the probability of further nucleation events. Again, a lower modeled minimum particle diameter is needed to properly account for the growth of particles from a few nanometers to CCN sizes.

The parameterization of the lake surface emissions flux is itself another significant source of uncertainty in this work. For the simulations presented here, it was assumed that the total number of particles emitted at the freshwater lake surfaces could be reasonably described by the parameterization of Geever et al. (2005), even though the latter was based on data collected over ocean rather than fresh water. To some extent uncertainty associated with the choice of emissions flux parameterization is unavoidable - many models for estimating wind-driven marine aerosol fluxes have been proposed, and they can result in very different flux estimations (Lewis and Schwartz, 2004). However, adapting a marine parameterization for fresh water requires some major assumptions about the nature of the aerosol production mechanism over marine and fresh water bodies. In its most basic conceptualization, marine particles are formed when droplets are ejected from the ocean surface and subsequently evaporate to leave a residual particle. If the ejection process is completely independent of surface chemistry, then applying a marine number flux parameterization to fresh water conditions is reasonable - the residual particles produced should be smaller in the latter case but they should be equally abundant. However, recent suggest strongly that ocean surface chemistry does play a significant role in regulating marine 
emissions (O'Dowd and De Leeuw, 2007). In this circumstance the marine flux parameterizations would not be transferable to fresh water conditions. At present no better option is available but this source of uncertainty should be studied more closely in the future.

Despite the limitations of the current model, our simulation results suggest that lake-generated ultrafine particles have the potential to impact aerosol number concentrations in the Great Lakes region. Further studies should be carried out to both better characterize the lake surface source via in-situ measurements and to model the impacts of these particles on the regional aerosol population throughout the year. This study was based on only a two-week period in July of 2004. Monitoring data indicates that July 2004 was a normal July, and that wind speeds over the Great Lakes during summer months are relatively low compared to other seasons (National Data Buoy Center, http://www.ndbc.noaa.gov/). During fall and late spring, when wind speeds are higher and the lakes are not covered by ice, the contribution of lake aerosols is likely to be greater. Moreover, the anticipated climatic changes for the Great Lakes region in the coming decades could further enhance the lake surface aerosol source. Summertime (July-September) wind speeds over Lake Superior have been increasing since 1985, likely due to climate warming (Desai et al., 2009). This increasing trend in wind speeds combined with reduced ice cover (also predicted under global warming scenarios) means that the emissions of lake aerosols will increase in intensity in the future and that its contributions will extend further into the early winter and late spring seasons when historically the northern Great Lakes have been frozen over.

Acknowledgements. Funding for this work was provided by NSF awards AGS-0904214 and AGS-0941129. Brett Basarab participated in "Atmospheric Chemistry and Climate Change: Measurements and Modeling in the Pacific Northwest", an NSF-sponsored Research Experience for Undergraduates program at WSU (NSF award AGS-0754990). We thank G. Grell, E. Hsie, S. McKeen, and G. Frost of NOAA Earth System Research Laboratory for their assistance with the WRF-Chem simulations.

Edited by: J. Fuentes

\section{References}

Carroll, M., Bertman, S. and Shepson, P.: Overview of the Program for Research on Oxidants: PHotochemistry, Emissions, and Transport (PROPHET) summer 1998 measurements intensive, J. Geophys. Res.-Atmos., 106, 24275-24288, 2001.

Carslaw, K. S., Boucher, O., Spracklen, D. V., Mann, G. W., Rae, J. G. L., Woodward, S., and Kulmala, M.: A review of natural aerosol interactions and feedbacks within the Earth system, Atmos. Chem. Phys., 10, 1701-1737, doi:10.5194/acp-10-17012010, 2010.
Chen, F. and Dudhia, J.: Coupling an advanced land surfacehydrology model with the Penn State-NCAR MM5 modeling system, Part I: Model implementation and sensitivity, Mon. Weather Rev., 129, 569-585, 2001.

Chou, M. D. and Suarez, M. J.: An efficient thermal infrared radiation parameterization for use in general circulation models, NASA Tech. Memo. available at: http://citeseerx.ist.psu.edu/ viewdoc/summary?doi=10.1.1.26.4850, last acces: 16 March 2011, 1994.

Claeys, M., Graham, B., Vas, G., Wang, W., Vermeylen, R., Pashynska, V., Cafmeyer, J., Guyon, P., Andreae, M. O., Artaxo, P., and Maenhaut, W.: Formation of Secondary Organic Aerosols Through Photooxidation of Isoprene, Science, 303, 1173-1176, doi:10.1126/science.1092805, 2004.

Desai, A. R., Austin, J. A., Bennington, V., and McKinley, G. A.: Stronger winds over a large lake in response to weakening air-to-lake temperature gradient, Nature Geosci., 2, 855-858, doi:10.1038/ngeo693, 2009.

Fast, J. D., Gustafson, W. I., Easter, R. C., Zaveri, R. A., Barnard, J. C., Chapman, E. G., Grell, G. A. and Peckham, S. E.: Evolution of ozone, particulates, and aerosol direct radiative forcing in the vicinity of Houston using a fully coupled meteorology-chemistry-aerosol model, J. Geophys. Res.Atmos., 111, D21305, doi:10.1029/2005JD006721, 2006.

Frost, G., McKeen, S., Trainer, M., Ryerson, T., Neuman, J., Roberts, J., Swanson, A., Holloway, J., Sueper, D., Fortin, T., Parrish, D., et al.: Effects of changing power plant NOx emissions on ozone in the eastern United States: Proof of concept, Journal of Geophysical Research-Atmospheres, 111(D12), doi:10.1029/2005JD006354, 2006.

Geever, M., O’Dowd, C., van Ekeren, S., Flanagan, R., Nilsson, E., de Leeuw, G., and Rannik, U.: Submicron sea spray fluxes, Geophys. Res. Lett., 32, L15810, doi:10.1029/2005GL023081, 2005.

Gong, S. L., Barrie, L. A., Prospero, J. M., Savoie, D. L., Ayers, G. P., Blanchet, J. P., and Spacek, L.: Modeling sea-salt aerosols in the atmosphere 2. Atmospheric concentrations and fluxes, J. Geophys. Res.-Atmos., 102, 3819-3830, 1997.

Grell, G. A. and Devenyi, D.: A generalized approach to parameterizing convection combining ensemble and data assimilation techniques, Geophys. Res. Lett., 29, 1693, doi:10.1029/2002GL015311, 2002.

Grell, G. A., Peckham, S. E., Schmitz, R., McKeen, S. A., Frost, G., Skamarock, W. C., and Eder, B.: Fully coupled "online" chemistry within the WRF model, Atmos. Environ., 39, 6957-6975, doi:10.1016/j.atmosenv.2005.04.027, 2005.

Gustafson, W. I., Chapman, E. G., Ghan, S. J., Easter, R. C. and Fast, J. D.: Impact on modeled cloud characteristics due to simplified treatment of uniform cloud condensation nuclei during NEAQS 2004, Geophys. Res. Lett., 34, L19809, doi:10.1029/2007GL030021, 2007.

Henze, D. K. and Seinfeld, J. H.: Global secondary organic aerosol from isoprene oxidation, Geophys. Res. Lett., 33, L09812, doi:10.1029/2006GL025976, 2006.

Hong, S. Y. and Pan, H. L.: Nonlocal boundary layer vertical diffusion in a Medium-Range Forecast Model, Mon. Weather Rev., 124, 2322-2339, 1996.

Hong, S. Y., Dudhia, J., and Chen, S. H.: A revised approach to ice microphysical processes for the bulk parameterization of clouds 
and precipitation, Mon. Weather Rev., 132, 103-120, 2004.

IPCC: Climate Change 2007: The Physical Science Basis, Intergovernmental Panel on Climate Change, Cambridge University Press, Cambridge, UK and New York, USA., 2007.

Jacobson, M. Z.: Development and application of a new air pollution modeling system - II, Aerosol module structure and design, Atmos. Environ., 31, 131-144, doi:10.1016/13522310(96)00202-6, 1997.

Jacobson, M. Z., Turco, R. P., Jensen, E. J., and Toon, O. B.: Modeling coagulation among particles of different composition and size, Atmos. Environ., 28, 1327-1338, 1994.

Janjic, Z. I.: Nonsingular implementation of the Mellor-Yamada Level 2.5 scheme in the NCEP Meso model, National Centers for Environmental Prediction., 2002.

Kim, S. W., Heckel, A., McKeen, S. A., Frost, G. J., Hsie, E. Y., Trainer, M. K., Richter, A., Burrows, J. P., Peckham, S. E. and Grell, G. A.: Satellite-observed US power plant NOx emission reductions and their impact on air quality, Geophys. Res. Lett., 33, doi:10.1029/2006GL027749, 2006.

Kroll, J. H., Ng, N. L., Murphy, S. M., Flagan, R. C., and Seinfeld, J. H.: Secondary organic aerosol formation from isoprene photooxidation, Environ. Sci. Technol., 40, 1869-1877, doi:10.1021/es0524301, 2006.

Kuang, C., McMurry, P. H., and McCormick, A. V.: Determination of cloud condensation nuclei production from measured new particle formation events, Geophys. Res. Lett., 36, L09822, doi:10.1029/2009GL037584, 2009.

Kulmala, M., Vehkamaki, H., Petaja, T., Dal Maso, M., Lauri, A., Kerminen, V., Birmili, W., and McMurry, P.: Formation and growth rates of ultrafine atmospheric particles: a review of observations, J. Aerosol Sci., 35, 143-176, doi:10.1016/j.jaerosci.2003.10.003, 2004.

Lewis, E. R. and Schwartz, S. E.: Sea salt aerosol production: mechanisms, methods, measurements and models?: a critical review, American Geophysical Union, 2004.

Mårtensson, E. M., Nilsson, E. D., Leeuw, G. de, Cohen, L. H., and Hansson, H.-C.: Laboratory simulations and parameterization of the primary marine aerosol production, J. Geophys. Res., 108, 12 pp., doi:200310.1029/2002JD002263, 2003.

McKeen, S., Chung, S. H., Wilczak, J., Grell, G., Djalalova, I., Peckham, S., Gong, W., Bouchet, V., Moffet, R., Tang, Y., Carmichael, G. R., Mathur, R., and Yu, S.: Evaluation of several $\mathrm{PM}_{2.5}$ forecast models using data collected during the ICARTT/NEAQS 2004 field study, J. Geophys. Res.-Atmos., 112, D10S20, doi:10.1029/2006JD007608, 2007.

McKeen, S., Grell, G., Peckham, S., Wilczak, J., Djalalova, I.,Hsie, E. Y., Frost, G., Peischl, J., Schwarz, J., Spackman, R., Holloway, J., deGouw, J., Warneke, C., Gong, W., Bouchet, V., Gaudreault, S., Racine, J., McHenry, J., McQueen, J., Lee, P., Tang, Y., Carmichael, G. R., and Mathur, R.: An evaluation of realtime air quality forecasts and their urban emissions over eastern Texas during the summer of 2006 Second Texas Air Quality Study field study, J. Geophys. Res.-Atmos., 114, D00F11, doi:10.1029/2008JD011697, 2009.

Mellor, G. L. and Yamada, T.: Development of a turbulence closuremodel for geophysical fluid problems, Rev. Geophys., 20, 851875, 1982.

Merikanto, J., Spracklen, D. V., Mann, G. W., Pickering, S. J., and Carslaw, K. S.: Impact of nucleation on global CCN, At- mos. Chem. Phys., 9, 8601-8616, doi:10.5194/acp-9-8601-2009, 2009.

Mlawer, E. J., Taubman, S. J., Brown, P. D., Iacono, M. J., and Clough, S. A.: Radiative transfer for inhomogeneous atmospheres: RRTM, a validated correlated-k model for the longwave, J. Geophys. Res.-Atmos., 102, 16663-16682, 1997.

Nilsson, E., Rannik, U., Swietlicki, E., Leck, C., Aalto, P., Zhou, J., and Norman, M.: Turbulent aerosol fluxes over the Arctic Ocean 2. Wind-driven sources from the sea, J. Geophys. Res.-Atmos., 106, 32139-32154, 2001.

Ntelekos, A. A., Smith, J. A., Donner, L., Fast, J. D., Gustafson, W. I., Chapman, E. G. and Krajewski, W. F.: The effects of aerosols on intense convective precipitation in the northeastern United States, Q. J. Roy Meteorol. Soc., 135(643), 1367-1391, doi:10.1002/qj.476, 2009.

O'Dowd, C. and De Leeuw, G.: Marine aerosol production: a review of the current knowledge, Philos. T. Roy. Soc. A, 365, 1753-1774, doi:10.1098/rsta.2007.2043, 2007.

O’Dowd, C. D., Geever, M., Hill, M. K., Smith, M. H., and Jennings, S. G.: New particle formation: Nucleation rates and spatial scales in the clean marine coastal environment, Geophys. Res. Lett., 25(10), 1661-1664, 1998.

O’Dowd, C. D., Jimenez, J. L., Bahreini, R., Flagan, R. C., Seinfeld, J. H., Hameri, K., Pirjola, L., Kulmala, M., Jennings, S. G. and Hoffmann, T.: Marine aerosol formation from biogenic iodine emissions, Nature, 417, 632-636, 2002.

O’Dowd, C., Langmann, B., Varghese, S., Scannell, C., Ceburnis, D., and Facchini, M.: A combined organic-inorganic sea-spray source function, Geophys. Res. Lett., 35, L01801, doi:10.1029/2007GL030331, 2008.

Pandis, S. N., Paulson, S. E., Seinfeld, J. H., and Flagan, R. C.: Aerosol formation in the photooxidation of isoprene and betapinene, Atmos. Environ., 25, 997-1008, 1991.

Pierce, J. R. and Adams, P. J.: Uncertainty in global CCN concentrations from uncertain aerosol nucleation and primary emission rates, Atmos. Chem. Phys., 9, 1339-1356, doi:10.5194/acp-91339-2009, 2009.

Seinfeld, J. H. and Pandis, S. N.: Atmospheric Chemistry and Physics: From Air Pollution to Climate Change, 2nd edn., WileyInterscience, 2006.

Simmel, M. and Wurzler, S.: Condensation and activation in sectional cloud microphysical models, Atmos. Res., 80, 218-236, doi:10.1016/j.atmosres.2005.08.002, 2006.

Skamarock, W. C., Klemp, J. B., Dudhia, J., Gill, D. O., Barker, M., Wang, W., and Powers, J. G.: A description of the advanced research WRF version 2, NCAR, 2005.

Slade, J. H., VanReken, T. M., Mwaniki, G. R., Bertman, S., Stirm, B., and Shepson, P. B.: Aerosol production from the surface of the Great Lakes, Geophys. Res. Lett., 37, L18807, doi:10.1029/2010GL043852, 2010.

Tzivion, S., Feingold, G., and Levin, Z.: The evolution of raindrop spectra part 2: Collisional collection breakup and evaporation in a rainshaft, J. Atmos. Sci., 46, 3312-3327, 1989.

Weber, R. J., McMurry, P. H., Mauldin, R. L., Tanner, D. J., Eisele, F. L., Clarke, A. D., and Kapustin, V. N.: New particle formation in the remote troposphere: A comparison of observations at various sites, Geophys. Res. Lett., 26, 307-310, 1999.

Wexler, A., Lurmann, F. W., and Seinfeld, J. H.: Modeling urban and regional aerosols: 1. Model development, Atmos. Environ., 
28, 531-546, 1994.

Yu, F. and Luo, G.: Simulation of particle size distribution with a global aerosol model: contribution of nucleation to aerosol and CCN number concentrations, Atmos. Chem. Phys., 9, 76917710, doi:10.5194/acp-9-7691-2009, 2009.

Zaveri, R. A. and Peters, L. K.: A new lumped structure photochemical mechanism for large-scale applications, J. Geophys. Res.Atmos., 104, 30387-30415, 1999.

Zaveri, R. A., Easter, R. C., and Peters, L. K.: A computationally efficient multicomponent equilibrium solver for aerosols (MESA), J. Geophys. Res.-Atmos., 110, D24203, doi:10.1029/2004JD005618, 2005a.

Zaveri, R. A., Easter, R. C., and Wexler, A. S.: A new method for multicomponent activity coefficients of electrolytes in aqueous atmospheric aerosols, J. Geophys. Res.-Atmos., 110, D02201, doi:10.1029/2004JD004681, 2005b.

Zaveri, R. A., Easter, R. C., Fast, J. D., and Peters, L. K.: Model for simulating aerosol interactions and chemistry (MOSAIC), J. Geophys. Res.-Atmos., 113, D13204, doi:10.1029/2007JD008782, 2008.
Zhang, Y., Liu, P., Liu, X. H., Jacobson, M. Z., McMurry, P. H., Yu, F. Q., Yu, S. C., and Schere, K. L.: A comparative study of nucleation parameterizations: 2. Three-dimensional model application and evaluation, J. Geophys. Res.-Atmos., 115, D20213, doi:10.1029/2010JD014151, 2010a.

Zhang, Y., Wen, X. Y., and Jang, C. J.: Simulating chemistryaerosol-cloud-radiation-climate feedbacks over the continental US using the online-coupled Weather Research Forecasting Model with chemistry (WRF/Chem), Atmos. Environ., 44, 3568-3582, doi:10.1016/j.atmosenv.2010.05.056, 2010 b.

Zhao, C., Liu, X., Leung, L. R., Johnson, B., McFarlane, S. A., Gustafson Jr., W. I., Fast, J. D., and Easter, R.: The spatial distribution of mineral dust and its shortwave radiative forcing over North Africa: modeling sensitivities to dust emissions and aerosol size treatments, Atmos. Chem. Phys., 10, 8821-8838, doi:10.5194/acp-10-8821-2010, 2010. 